\title{
The Battlefield of Australian History
}

\author{
Rachel Nasr
}

University of Technology Sydney, Faculty of Arts and Social Sciences, PO Box 123, Ultimo NSW 2007, Australia.rachel.nasr@student.uts.edu.au

One question that has permeated throughout history and continues to persist today, attracting much controversy amongst academics seems to be whether or not historians have provided an accurate account of Aboriginal history. This week 2 topic, The Battlefield of Aboriginal History, particularly offers valuable insights as individuals continue to wrangle this question, paving the way for reconciliation by proposing alternate methods of Aboriginal representation that promote authenticity.

\section{Can historians tell the truth?}

Most notably, this topic forces readers to consider historians 'inattention' to the truths of Aboriginal Australian history, conceptualised as a 'cult of forgetfulness practised on a national scale' (Stanner 1969, p. 24). Stanner prompts respondents to question what might typically be deemed as accurate documentation of Australian history. He posits that Australia has been plagued by an inclination to conceal their wrongdoings by choosing to call out false recounts, instead of complacently accepting that 'the white man did the black man very little wilful harm' (Stanner 1969, p. 22). In recognising the violent paradigms that dictated our current narratives, respondents are able to consider history in a new light. Described by Windschuttle as 'myth piled upon myth' (Windschuttle 2002, p. 22), it is important for individuals to practice caution when relying on these white-supremacist theories as a source of truth. Most notably, their harm manifests in their potential to 'liquidate and diminish the oldest civilisation which has survived indigenocide' (Evan \& Thorpe 2001, 38). Although 'The Great Australian Silence' prompted a change from a number of historians, the problem of historians telling the truth remains a past and present issue.

\section{How Aboriginal History Should Be Told}

'Australians generally had great difficulty in coming to terms with their colonial past' (Curthoys 2008, p. 238), nevertheless, it is critical for historians and academics to delineate an authentic image of the past, despite its heinous truths. 'Getting history wrong will, in the long term, mean that lasting solutions will be sort in the wrong places' (Harris 2003, p. 80), 
therefore, 'a different kind of history' (Curthoys 2008, p. 238) is required. The history of Aboriginal Australian peoples must be told in a new light where the community is no longer treated as 'a melancholy footnote' (Stanner 1969, p. 25), but instead celebrated for their perseverance against the barbaric actions of white Australia. Inevitably, historians themselves will always carry some degree of bias in their recounts and therefore when sourcing an accurate depiction of the past, caution must be practised. When considering the most appropriate method on how to write Aboriginal history, individuals can only highlight the truths of the past through a recognition that our current understanding has been told through the lens of the white supremacist.

\section{References}

Curthoys, A. 2008, 'WEH Stanner and the historians', in Hinkson, M., and Beckett, J., (eds), An Appreciation of Difference: WEH Stanner and Aboriginal Australia, Canberra, Aboriginal Studies Press, pp 233-250.

Evans, R \& Thorpe, B. 2001, 'Indigenocide and the massacre of Aboriginal history,' Overland, No. 163, Winter, pp. 21-39, viewed 12 May 2019, <https://search.informit.com.au/documentSummary; dn=200112842;res=IELAPA >.

Harris, J. 2003, 'Hiding the Bodies: the Myth of the Humane Colonisation of Aboriginal Australia,' Aboriginal History, vol. 27, pp. 79-104, JSTOR, viewed 11 May 2019, <www.jstor.org/stable/24054261>.

Stanner, W. E. H. 1969, 'The Great Australian Silence' The 1968 Boyer Lectures: After The Dreaming, Sydney, ABC Enterprises, pp 18-29.

Windschuttle, K. 2002, The fabrication of Aboriginal history, Macleay Press, Sydney, p. 22. 